\title{
Governance structure promoting innovation: an exploratory study in Brazilian habitats
}

\author{
Rafael Pereira Ocampo Morée ${ }^{*}$, Cláudio Reis Gonçalo², Gabriela Gonçalves Silveira Fiates ${ }^{1}$, \\ Cristiana Rennó D’Oliveira Andrade ${ }^{2}$
}

\begin{abstract}
This research aimed to investigate how the governance structure of innovation habitats may contribute to the development of innovation in resident companies. An exploratory study was conducted in INOVAPARQ and CELTA incubator, in Brazil. The empirical contexts were investigated by applying qualitative method with NVivo software. Critical success factors of governance were found: managerial relationships with different stakeholders; national and international training networks; and boosted resident companies monitoring by specific assessment tools. It was concluded that these factors are crucial to the innovation process of resident companies mostly by creating new products and services; sharing of inter-company knowledge; and motivating employees to work in a creative environment.
\end{abstract}

Keywords: Absorptive Capacity; Innovation Habitats; Governance Structure

Submitted: August $20^{\text {th }}, 2018 /$ Approved: November $13^{\text {th }}, 2018$

\section{Introduction}

This research aimed to investigate how the governance structure of innovation habitats may contribute to the development of innovation in resident companies. Moreover, how the structure of this governance scenery may stimulate the management council capable of presenting effective guidelines for the innovative development of the enterprises. We argued that such development should reflect at least effectiveness by sharing strategic resources (Robeson \& O'connor, 2007; Mattor et al., 2014, Filipova, Drozen \& Kubankova, 2016, Kapounek \& Krutilova, 2016).

Environments of intense exchange of experience can lead to the acquisition, transformation, assimilation and application of knowledge from new insights, which may lead innovations towards the market (Zahra \& George, 2002, Fosfuri \& Tribo, 2008, Caner, Sun, Prescott, 2014, Xie, Wang \& Zeng, 2018). As a result of this dissemination of information and knowledge, these actions can, due to the outlined strategies, minimize the impact of external forces on the environment and create innovations that could enhance the society with new services or products. Innovation habitats environments, that aim to boost productivity and innovation of resident enterprises, perform as agents of information and knowledge transfer for the promotion of new business and generation of new ideas (Stopper, 1995, Tonelli \& Zambalde, 2007, Fallows, 2013). Those may be able to become specialized in a particular industry, such as information technology, in which stakeholders may create specific services or products to attend market and society (Zouain, 2003, Mills, Reynolds \& Reamer, 2008, Virtanen, Heimonen \& Sepponen, 2014, Sureeyatanapas, Poophiukhok \& Pathumnakul, 2018).

There are distinct governance arrangement models for innovation habitats and it is relevant to understand how different structures of governance can optimize actions to support the business and the technology transmission towards innovation (Ma, Kaldenbach \& CI, 2014, Wang, Chan \& Fang, 2018). Therefore, it is necessary to clarify how different governance actions can effectively contribute such to the process of innovation as to the sustainable development of resident companies.

The stakeholders in innovation habitats promote the sustainability of their business by the promotion of innovation, on which the governance structure pursues contributing to the arrangement of partner's networks that are able to work with synergy and achieve common goals (Humphrey, Schmitz, 2000, Mueller, Schmidt \& Kuerbis, 2013, Vega-Jurado, Kask \& Manjarrés-Henriquez, 2017).

Beyond the understanding of how the development of governance structure in innovation habitats can countersign the creation of absorptive and innovation capabilities in enterprises, it is also discussed the development of governance actions creating an adequate structure focused on knowledge exchange and innovation within and among companies.

\section{Theoretical Background}

\section{Governance Structure}

The study of governance and its possible applications in management have been monitored and improved in recent decades, especially in developed countries, highlighting the United States and Britain practices. Hence, literature, laws, social customs, modes of governance, organizational forms, and industry structures are compared in terms of their incentives, economic consequences, and ability to survive and grow in a given historical setting or technological context (Baldwin \& Von Hippel, 2011).

(1) Programa de Pós-Graduação em Administração Universitária, Federal University of Santa Catarina, Florianópolis, SC, Brazil.

(2) Programa de Pós-Graduação em Administração, University of Vale do Itajaí, Biguaçu, SC, Brazil.

${ }^{*}$ Corresponding author: rafael.more@ufsc.br 
However, the formation of innovation habitat enhances specific subject knowledge, in which the competitive governance structure construction insertion passes through the establishment of the structure, elements and governance actions. Also, in this context, Schmidt and Balestrin (2015) investigated the collaborative R\&D network in innovation habitats proposing that such environments devise a strategic role in providing services and infrastructure to support collaboration, innovation and development of resident companies.

The governance structure denotes actions developed by a behavioral perspective. Factually, governance is related to mechanisms designed to control the resources of companies, based on key stakeholder's management interests of that influence companies through their proportional interests to applied resources and desired returns (Groenewegen, 2004). However, it is necessary to accompany all governance changes that occur during the growth stages of organizations (Bernstein, 2012).

Governance can also be understood as a plural and integrating concept, which differs from the concept of management. It translates into joint agents, businessmen, third sector, governments of various levels and other segments of society, able to be represented in projects and plans related to a utopian city with quality of life and, also, a broad sustainability or shared leadership (Kaufmann, Kraay \& Mastruzzi, 2006). This includes the process by which governments are selected, monitored and replaced; the capacity of the government to effectively formulate and implement sound policies; and the respect of citizens and the state for the institutions that govern economic and social interactions among them. Also, this process is the result of a constant and effective dialogue between the government and civil society to create institutional spaces of political decentralization, interfering with the practice in training managers who will work the front organizations (Kaufmann, Kraay \& Mastruzzi, 2018).

Practically, it can be eminent that governance structures are created to quickly remedy current problems and future. By developing the effective governance system, problems such as slow decision-making process, due to bureaucracy and incomplete organizational structures can be solved in a more dynamic interpretation of the market and thus make the company more competitive.

In communal environments, governance needs to be analyzed under three joint perspectives: influence of the agents; agility in decision making; and accountability (Bobbio, 1987). Those agents are the actors who will constitute the governance of a particular organizational structure need. This structure, though, is composed in order to have power to influence actions to be implemented, have good relationships and dynamism facing an agile decision-making process. In the governance's arrangement process, one can still check agency problems (Saito \& Silveira, 2008) related to conflicts between shareholders and managers.

Those conflicts are caused by socio-cultural shocks and organizational models consist of rules, specific rules and routines. To alleviate this "clash", it is needed to establish and provide clear guidelines that are known to all stakeholders (Scott, 1987, Scott, 2004 \& Adegbite, 2015).
Many innovation systems studies regarding innovation habitats consider institutions often change slowly. And, so, the generation of innovation may be affected considering the dependence that exists between organizations and institutions (Werle 2011, Pipan, Gomiscek \& Mayer, 2012). In other words, slow institutions and lengthy decision-making processes involve less innovative and less degree of competitiveness. Also in this context for organizational development, the balance of strength and power industry with their companies is required.

We consider that the governance structure should encourage the development of a capable management council to provide effective guidelines for the innovative development of enterprises. This may reflect the creation of absorptive capacity and innovation capacity, designed from the sharing of strategic resources (Robeson \& O'connor, 2007, Mattor et al, 2014).

From this conceptual analysis, we present the theoretical proposition 1 as follows: the governance structure of an innovation habitat contributes to the process of innovation in resident companies.

\section{Absorptive Capacity}

Firstly, we analyzed the concept of absorptive capacity as necessary to obtain records assuring that this field of application theory addresses the capabilities of companies or individuals to use organizational resources to generate products or services. In these terms, companies or individuals must be able to make something out of the conditions and targeting factors are needed to reach a particular purpose (Zahra, Sapienza \& Davidsson, 2006).

In a practical way, the development of different capacities by companies allows them to explore new market opportunities from offering unique products and services. Thus, Table 1 identifies six types of capabilities arising from the internal and external environments. These capabilities interface with organizations and their knowledge presented in the experience and in its life cycle (exploration, retention and exploitation). They can be defined as: inventive, absorptive, transformative, connective, innovative and disruptive (Lichtenthäler \& Lichtenthäler, 2010).

Table 1. Interfaces of knowledge. Data from Lichtenthaler and Lichtenthaler (2010).

\begin{tabular}{l|l|l|l}
\hline & $\begin{array}{l}\text { Knowledge } \\
\text { Exploitation }\end{array}$ & $\begin{array}{l}\text { Knowledge } \\
\text { Retention }\end{array}$ & $\begin{array}{l}\text { Explicit } \\
\text { Knowledge }\end{array}$ \\
\hline Intern (Intrafirm) & $\begin{array}{l}\text { Inventive } \\
\text { capacity }\end{array}$ & $\begin{array}{l}\text { Transformative } \\
\text { capacity }\end{array}$ & $\begin{array}{l}\text { Innovative } \\
\text { capacity }\end{array}$ \\
\hline Extern (Interfirm) & $\begin{array}{l}\text { Absorptive } \\
\text { capacity }\end{array}$ & $\begin{array}{l}\text { Connective } \\
\text { capacity }\end{array}$ & $\begin{array}{l}\text { Disruptive } \\
\text { capacity }\end{array}$ \\
\hline
\end{tabular}

By analysing Table 1, we understood that the capacity and the organization's ability to create, or expand or modify its resource base, both internal and external (Lichtenthäler \& Lichtenthäler, 2010).

Regarding absorptive capacity, measure these ability is still a challenge for researchers and companies (Flatten et al, 2011), regarding the fact that a valid measure that incorporates the various dimensions of 
absorptive capacity has not yet been developed. This may occur, for example, that the definition of metric often arises in the result of a no consensus regarding the dimensions that compose the construct, resulting in the need to introduce which model absorptive ability is being adopted in the search.

Moreover, Schreyöegg and Kliesch-Eberl (2007) also claim that for a company to be innovative is also expected that it has a minimum capacity set to run its core activities, seeking mature and evolve in pursuit of innovation. This innovation is focused on the process and not isolated events, including the implementation of changes in products / services, organizational and managerial processes and systems (Veugelers, 1997, Veugelers \& Cassiman, 2000, Schreyöegg \& Kliesch-Eberl, 2007).

Thus, considering the importance of the strategic use of internal resources of the company to contribute to the process of innovation and development of its capabilities (Cohen \& Levinthal, 1990, Zahra \& Geroge, 2002, Lichtenthäler \& Lichtenthäler, 2010, Flatten et al, 2011), it is necessary to introduce some definitions regarding strategic resources.

Initially, Teece, Pisano and Shuen (1997) conceptualize resources as the strengths that companies can use to design and implement their organizational strategies, resulting in innovative products or services. In this case, an analysis based on internal resources is important to identify a sustainable competitive advantage derived from dissatisfaction and/or failure of external action contributions or relationship with the environment in business development (Foss, 1997). The resource-based perspective also seeks to understand which existing conditions are able to generate income or lasting competitive advantage (Barney, 1991, 1995, Peteraf, 1993, Amit \& Schoemaker, 1993, Barney \& Hesterly, 2012).

Thus, valuing the adopted strategies, improve business performance in a high degree of unpredictability and dynamic environments and provide a privileged position within its operating environment can result in a more effective innovation process (Maurer, Bansal \& Crossan, 2010).

In order to develop harmony and effectiveness in the system generated by a given habitat, it is necessary that its strategic resources, as well as the resident companies, are constant in line and assist in capacity building, since companies with resource problems and difficulties in developing the skills can result in low value-added innovation and a limited competitive potential.

Specifically, considering the absorptive capacity as a result of the strategic management of resources, Zahra and George (2002) point out that it can be turned to "potential absorption capacity", including the acquisition of knowledge and assimilation capacity, and the "absorption performed capacity", which has its heart in the transformation and exploitation of knowledge. It should be noted that the strategic resources represent knowledge that is being worked on.

There are other empirical studies on the relationship between the variables of absorption capacities and efforts to innovation, on which there is evidence that they are positively correlated (Cohen \& Levinthal, 1989, 1990, Veugelers, 1997, Becker \& Peters, 1998). Emphasis is also given to the fact that the present absorption capacity of a company depends on the efforts it made to innovate in the past (Cohen \& Levinthal, 1990).

Finally, the concept of absorptive capacity in this research is the actions target at acquisition, transformation, assimilation and exploitation of knowledge, in which the company depends on the absorption capacity of its individual employees and the form in which it will be developed in search to effectiveness.

From this conceptual analysis, we present the theoretical proposition 2: the absorptive capacity of companies' resident in innovation habitats contributes to innovativeness in products, services or processes.

\section{Innovation capacity}

The process of creating an environment driven to innovation is vital in the development of enterprises and the generation of products and services that meet the interests of society and the market, however, the understanding of this environment goes, at first, the meaning of innovation. Since Schumpeter (1997), innovations represent new combinations: marketing techniques translated by new business combinations; and organizational, in the form of new business organizations. Innovation may be related to the exploration of opportunities for companies delineating precisely the borders that delimit the space of each niche market, so as to improve and meet underserved market for new services (Pavitt, 2004).

The variables - time and speed - are strategic elements for companies seeking competitive advantages of experience in the market (products or differentiated services). And considering the pressures and needs of society and the market, are also essential to the process of innovation, as the life cycles of products and the time of its developments are increasingly short, in a scenario where the customers expect service and prompt delivery of products (OECD, 2005).

In this context, characterized by intense competition and market pressures increasing, it is recorded that the intensity of competition, rapid globalization and the constant changes in information technology make the inevitable innovation for businesses as a way to capture opportunities through the development of new products and the market itself (Hauknes, 1998, Lobianco \& Ramos, 2004, Kubota, 2009). Innovation processes may be aimed at generating knowledge based on strategic models that consider social and economic aspects, stimulating networking activities, avoiding isolated organizations (Hauknes, 1998, Lobianco \& Ramos, 2004, Kubota, 2009).

Thus, innovation can improve company performance by optimizing their ability to innovate and improve management processes of production, considering the application of new organizational practices and the development of entrepreneurial skills to acquire and generate new knowledge (OECD, 2005). 
In this investigation, the concept of knowledge is understood as the strategic use of data and information, through the application of methodologies and specific technologies. It allows people to develop innovative products and services that may be applied due to society's demands or market opportunities (Van De Bosch, Volberba \& Boer 1999, Zahra \& George, 2002, Fabrizio, 2009). So, it is understood innovativeness as developed behavioral actions and managed by companies, which potentiated by an environment that stimulates the generation of innovation, resulting in the creation of new products, services or in the improvement of processes.

However, in innovation habits environments some behavioral principles may restrict the innovation capacity of enterprises, and for this reason, companies will be called upon to develop their capacity to adapt to the early stages of development, such as, in conducting a project related to the understanding of new potential markets and customers. So, they can adjust to anticipated future demand mode (Biedenbach \& Muller, 2012).

In conclusion, from this conceptual analysis, we present the theoretical preposition 3 to be investigated: the absorptive capacity and innovation companies can be influenced by strategic actions of actors in the governance of innovation habitats. Before this, confirmed the demonstration of theories used for the analysis of the collected data, it is understood that the innovation habitats governance structure may represent a strategic factor in helping the resident companies in formulating strategies and generation of innovation through knowledge sharing among different stakeholders.

\section{Method}

\section{Procedure, Subjects or Participants}

Empirical studies conducted in Brazil have been applied in two prominent innovation habitats in national scenario and in Santa Catarina during the second half of 2015 and sought to expand knowledge with theories applied. Two cases were investigated: The Technological Innovation Park of Joinville and Region - INOVAPARQ and Business Center for Advanced Technology - CELTA.

INOVAPARQ is located in the city of Joinville, the largest city in the state of Santa Catarina, and came up with the goal of providing environments conducive to the practice of innovation, demand has increased more in the north of Santa Catarina (INOVAPARQ, 2015). Regarding the choice of resident companies representing INOVAPARQ habitat, Table 3 summarizes the main characteristics of the investigated companies.

Table 2. Total of INOVAPARQ companies and companies investigated.

\begin{tabular}{l|l|l|l}
\hline Number of companies / Practices Areas & Software Development & Biotechnology and environment & Others \\
\hline Total of 20 companies in INOVAPARQ & 12 & 3 & 5 \\
\hline Total of 8 investigated companies & 5 companies = EIP3, EIP4, EIP6, EIP7 e EIP8 & 2 companies = EIP1 e EIP5 & 1 company = EIP2 \\
\hline
\end{tabular}

In addition to the 8 investigated companies were interviewed three managers of INOVAPARQ, totaling 11 interviews. Regarding habitat inter- views the CELTA, which is located in Florianopolis, SC, Table 4 summarizes the main characteristics of the investigated residents' enterprises.

Table 3. Total companies in the CELTA and companies investigated

\begin{tabular}{l|l|l|l}
\hline Number of companies / Practice Areas & Software Development & Product Development & Others \\
\hline Total of 28 companies in CELTA & 10 & 10 & 8 \\
\hline Total of 9 investigated companies & $\begin{array}{l}5 \text { companies = EC1, EC2, EC3, } \\
\text { EC4 e EC9 }\end{array}$ & 2 companies = EC6 e EC7 & 2 companies = EC 8 e EC9 \\
\hline
\end{tabular}

Finally, it is noteworthy that in addition to the 9 investigated companies, were interviewed one CELTA managers, the principal manager, totaling 10 interviews in this habitat

It is important to point up that both innovation habitats investigated, INOVAPARQ and CELTA, can be regarded as national and international references in relation to their innovation environments and support geared to business development, highlighting, for example, the combination of both habitats to the national Association of entities Promoting Innovative Enterprises - ANPROTEC and the international Association of Science Parks and Areas of Innovation - IASP, these large national and international entities expression.

\section{Apparatus}

For the analysis of the contents of the interviews, it was used the qualitative analysis software Nvivo 10, produced by QSR
International. The software resources applied were: word counting and the network crossing of similar words present in the interviewees' speeches.

Finally, from the use of NVivo software, it can be performed the entire process of encoding and lexical analysis of the data, which facilitated the process of analyzing the extracted contents of the interviews; each collected information was tabulated considering the constructs and categories drawn from the framework.

\section{Design}

Faced with this empirical research context, it was identified as a research problem: How can the governance structure of an innovation habitat contribute to the development of the absorptive capacity and the innovation capacity of its companies? 
Thus, the theoretical propositions were assumed that guide the development of this research:

I. the governance structure of an innovation habitat can contribute to the development of capacities in companies.

II. the absorptive capacity of companies in innovation habitats can contribute to their capacity to innovate in products, services or processes.
III. the absorptive and innovation capacities of companies can be influenced by the actions proposed by the governance structure of innovation habitats.

For analysis and validation of the presented propositions, categories of analysis (Table 4) were identified in order to better understand the theoretical proposed model.

Table 4. Constructs, categories e indicators of analysis - theoretical framework

\begin{tabular}{l|l|l}
\hline Constructs & Categories & Indicators of analysis \\
\hline \multirow{4}{*}{ Governance } & Organizational structure & Legal model; Board activities and structure, Stakeholders; Management model \\
\cline { 2 - 3 } & Mechanisms of growth & $\begin{array}{l}\text { Internal and external actors; Capacity building; } \\
\text { Physical structure and shared services. }\end{array}$ \\
\cline { 2 - 3 } Absorptive capacity & Technology, innovation and networking & $\begin{array}{l}\text { Relationship with the market; Networking cooperation; Technologies and physical spaces; Fi- } \\
\text { nancing and allocation of resources }\end{array}$ \\
\cline { 2 - 3 } & Sustainability & Economic / Financial; Social; Environmental \\
\cline { 2 - 3 } & Opportunities for international relations & Integration with global markets; Participation and holding of events; International partnerships. \\
\cline { 2 - 3 } & Acquisition of knowledge & Events; Internal Networking; Business networks. \\
\cline { 2 - 3 } & Knowledge transformation & Conduction of meetings; Training and capacity building; Performance benchmarking \\
\hline \multirow{5}{*}{ Innovation Capacity } & Application of knowledge & Process innovation; Past experiences; Technologies. \\
\cline { 2 - 3 } & Stimulus to innovation Costs & Costs; Public Notices; Investors; Research and Development. \\
\cline { 2 - 3 } & Inovativity & Business Opportunities; Adequate environment; Participation policy. \\
\cline { 2 - 3 } & Creation & New technologies \\
\cline { 2 - 3 } & International Opportunities & New products or services; \\
\hline
\end{tabular}

It should be noted that the categories and indicators of the governance structure construct were developed from the authors Robeson and O'Connor (2007), and Mattor et al. (2014), which were used as the basis for the construction of the semi-structured questionnaire that was applied in Brazilian innovation habitats. Considering the categories and indicators of the construct of the absorptive capacity, these were based on the authors Cohen and Levinthal (1990), Zahra and George (2002), Fosfori and Tribó (2008) and Flatten et al. (2011). The categories and indicators of the innovation capacity construct were based on the following authors: Lichtenthaler and Lichtenthaler (2010), Chao et al. (2011) and Biedenbach and Müller (2012).

\section{Results}

Initially, it had been investigated the Technological Innovation Park of Joinville and Region - INOVAPARQ, which represents an important innovation habitat located in the city of Joinville, State of Santa Catarina. This park was created with the purpose of developing technology, economy and social aspects of northern Santa Catarina region by structuring and managing an environment that potentiate the scientific and technological research activities, technology transfer and the introduction of innovation in production and social environments. Also, aiming at favoring the creation and consolidation of projects to assist the development of new technologies, products and processes (Inovaparq, 2015).
Among the activities planned by INOVAPARQ management committee, provided in the statute, it is highlighted those related to the development and innovation of businesses, as well the whole system:

Encourage and cultivate innovative entrepreneurship;

To promote favorable conditions for the attraction of qualified human resources;

Establish or contribute to cooperation and partnerships between educational and research institutions, companies, government agencies, agencies and national and international organizations;

$>$ To support and enable operation on their premises or outside, enterprises focused on research and development of products, processes and / or services with potential for innovation; and

$>$ Search environmental sustainability in their activities and encourage the rational use of natural resources and clean technologies in enterprises installed on it.

It can be seen from these actions that, in some way, it may be related to activities that include functions of a habitat of innovation, as has the theoretical approach in the literature. For example, as portrayed Groenewegen (2004), governance is related to the creation of 
mechanisms aimed at the resources of the enterprise control from the management of the interests of key stakeholders, considering the resources applied and desired returns.

It should be noted that the current INOVAPARQ physical space is new, opened in August 2010 and has been receiving updates and investment in recent years. The current location of this park occurs because of land donated by the municipality of Joinville, and this space will also get in the coming years, the Innovation Center Joinville.

From what can be understood as critical success factors of INOVAPARQ governance, we presented a proposal for the realization of these factors that can portray this habitat's governance structure.

Figure 1. Critical success factors of INOVAPARQ governance structure

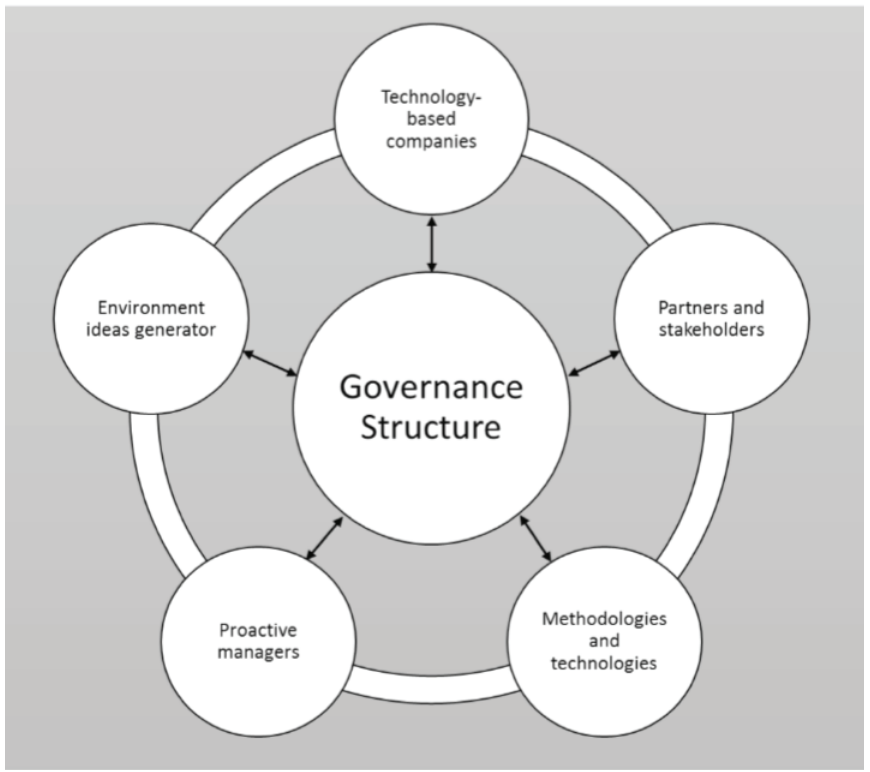

On Figure 1, the factors represent the search view that will guide the process of scientific research on the INOVAPARQ.

Initially, it is considered that the factor "technology companies" is the main profile of the companies that are installed in this habitat. These companies that represent the type of company most commonly found and incubated, scientific and technological park. The second feature noted from interviews and secondary data were the "partnership and stakeholders" of INOVAPARQ with different relationships, factor this decisive for the development and effectiveness of habitat as a reference environment in their region. The third factor noted was the "methodologies and technologies" used in the development and qualification of businesses, highlighting the CORE methodology, created by CELTA / CERTI Foundation, which helps in the evaluation of incubated companies.

The fourth factor is the "proactivity managers" of INOVAPARQ, this factor mentioned by several companies in the interviews and concerns the constant search for interaction and information transfer and knowledge of managers towards habitat companies.
The fifth and final critical factor found was "ideas generator room" which portrays the search in INOVAPARQ to develop recreational areas, botanical gardens, green areas and other physical spaces that may lead to the generation of ideas by resident companies.

It should be noted on Figure 4 that all features listed are related to the INOVAPARQ governance structure, to list: partnerships, proactive managers and innovative companies that are highlighted elements during interviews and secondary data, in which all these factors can contribute for the development of this habitat. The following information will be presented characterizing the governance structure of the CELTA.

CERTI Foundation - Reference Centers in Innovative Technologies Foundation in 1986 created the 1st Brazilian incubator of technology companies, the Business Center for the Elaboration of Innovative Technologies - CELTA, at the time called Business Technology Incubator - EIT. This incubator, a pioneer in Brazil, search from the beginning to support technology-based enterprises by encouraging and supporting the creation of new businesses. In general data, holds 36 technologybased companies that generate about 800 direct jobs and annual revenues of incubated reaches approximately R \$ 70 million (Celta, 2018).

This habitat also launched a system for monitoring and evaluation of companies based on Competitive Intelligence and Knowledge Management. From anywhere in the world the business owner can access the CELTA site and request or monitor their evaluation and can get market information, competitors, customers, products and technologies, which makes the system an important tool in the decisionmaking process of incubated companies.

These activities developed by CELTA confirm Graham et al. (2003) understanding of the governance organizational model strategic actions, because for these actors are necessary that managers responsible for governance develop activities for the development and business innovation, a fact verified in CELTA.

Markman et al. (2009) also have a similar governance model, which for the author can be guided by the identification of interests and incentives aimed at process management transfer of technology both by the management of habitats and by entrepreneurs that environment. These actions, in the specific case of CELTA, make up the search for the relationship of CELTA managers with existing companies through technologies developed.

The CELTA team also worked in the training and licensing of 400 consultants and incubator managers (those who assist incubators in the implementation of CERNE) and support for selection of 144 Brazilian incubators, which received financial support through the SEBRAE notice - ANPROTEC 02/2012 for the implementation of the pilot CERNE.

CELTA has about 28 incubated companies; all installed in their physical facilities, which are located in the Technological Park Alfa, in Florianópolis, SC. 
From what can be considered as critical success factors of the CELTA governance structure is presented a proposal for the characteristics to form the structure of this habitat model (Figure 2).

Figure 2. Critical success factors of CELTA governance structure

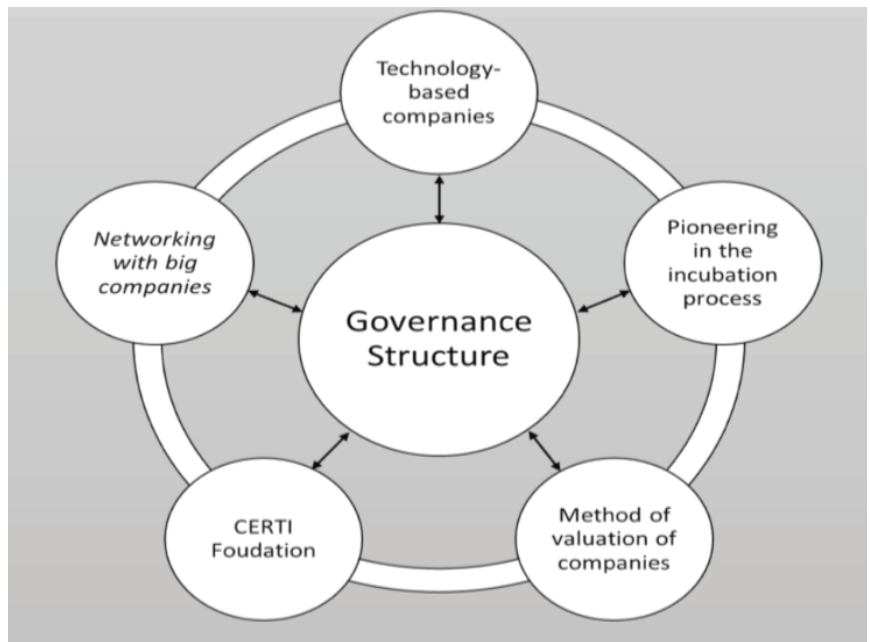

From Figure 3, explicit that "technology-based companies" represent the profile of CELTA's resident companies, which characterize the type of company most commonly found in incubators and in science and technology parks. The second feature identified concerns the "pioneering incubation process" of CELTA, which is the first incubator in Brazil, and therefore, can represent a national prominent factor in the incubation process.

The third element was the "CERNE methodology for valuation of companies", which was created by CELTA/CERTI Foundation and is currently used for many incubators in Brazil.

The fourth element is the very "CERTI Foundation", an organization that created the CELTA, and also participates in incubator management process, due to national prominence this foundation has in innovation activities, this factor may contribute to CELTA's development and growth.

The fifth element concerns the "Network" that CELTA has and seeks to build with large companies, this factor is pointed out by most of the companies during the interviews as something positive in their relationships with the market and that causes the appearance of new ideas.

\section{Framework of the innovation process in resident companies}

The qualitative research identifies specific success critical factors of each case investigated. It is known that these factors are structural investigated for these cases, however, depending on the case being analyzed, it can be revealing as long as there is representation, in other words, represents a benchmark. It is considered that the cases identified in this thesis permit progress in a theoretical proposition. It is recognized that this proposition still cannot be generalized. Thus, it is assumed a theoretical proposition in which should be further investigated through more qualitative research. This research will give conditions for quantitative investigations that confirm the designed model.
The framework proposed (Appendix 1) takes into consideration critical success factors identified in the investigations realized in the cases of INOVAPARQ and CELTA as empirical fields, beyond the exploratory study in the Spanish habitat CPI, looking to present some actions and key-process that applied in the context of innovation habitats can bring a differential development in the company.

According to the suggested structure, it can be seen that the actions related to the governance structure of innovation habitats, as well as the actions taken by companies in developing their absorptive capacity and innovation, that can take place in a systematic and related to each other.

In a global vision, it can be proposed with the analysis carried out in both cases studied that the contributions made by each innovation habitat indicate that governance actions contemplated in its structure and, when they are well executed, can enhance the development of absorptive capacity and innovation companies, a fact that is in line with what has been presented in the literature (Robeson, O'Connor, 2007; Zahra; George, 2002; Phosphoric, Tribe, 2008; Lichtenthäler; Lichtenthäler, 2010; Biedenbach; Muller 2012 ; Mattor et al, 2014).

Furthermore, the model (Appendix 1) depicts that this framework is not a closed system because the results achieved may be used as feedback by habitat managers, to design new actions and reform to those already existing.

Also in this framework, it had been tried to present critical success factors of all 14 categories developed from the three theoretical constructs in which, for each category defined in the theoretical model, it is identified representative actions of a determiner indicator.

For example, for the category "growth mechanism" the construct governance structure, it was presented an action related to the indicator development capabilities, in other words, the activities of monitoring and evaluation carried out by innovation habitats.

It is worth mentioning that the actions selected for the framework was considered the joint analysis of the two cases investigated, and from that, identify shares for both cases. That is, both the INOVAPARQ as to CELTA, for example, the relationship promoted with different stakeholders can contribute to the development of the absorptive capacity of companies.

It also emphasizes that every action presented by the governance structure of a given innovation habitat may be related to any activity undertaken by resident companies regarding the development of its absorptive capacity. Similarly, absorptive capacity of action may be related to any activity aimed at the development of their innovation capacity.

In other words, it can report, for example, that the formation of national and international networks promoted by innovation habitats can contribute to the exchange of experiences of companies, and can also strengthen the credibility of the habitat, in order to help resident companies' new business development and the search for new markets. 


\section{Discussion}

The aim of the research was to understand how the governance structure of innovation habitats may contribute to the development of innovation in resident companies. From the proposed framework, the critical factors were identified in successful governance structure that impacts the development of innovation in resident companies, investigated from the cases of INOVAPARQ and CELTA.

Thus, it was found that the governance actions were represented by: relationship promoted by habitats with different stakeholders; training of national or international networks with habitats and prestigious international educational institutions; and encouragement of practical innovation from specific notices. These actions effectively contributed to the development of innovation from: exchange of experiences in inter-company; strategic use by resident companies of information generated by evaluations of managers of habitats; and credibility of the habitat used as a recognition factor of the companies in the market.

In addition, actions were found of resident companies regarding the constant search for new investors; the creation of new technologies from the market needs monitoring; and the use of strategic information of evaluations and supervision carried out by habitats. These actions are resulted from the relationship built by the managers of habitats with its resident companies, and represent a competitive advantage of the system generated by habitats in the innovative development and economic sustainability. Finally, stimulating innovation it is also found in resident companies through the exchange of experiences and information with different stakeholders, which in addition to habitat credibility, result in the recognition of those companies by the market and the promotion of important trade agreements and internationalization processes countries of interest.

We also expect that the promotion and articulation of actors present in innovation habitats represent an applied contribution of the study, identifying facilitating elements so that the dialogue between habitat managers and companies can be enhanced.

\section{References}

Adegbite, E. (2015). Good corporate governance in Nigeria: Antecedents, propositions and peculiarities. International Business Review, 24 (2), $319-330$.

Amit, R. \& Schoemaker P. (1993). Strategic assets and organizational rent, Strategic Management Journal, 14, 33-46.

ANPROTEC - Associação Nacional de Entidades Promotoras de Empreendimentos Inovadores. (2015, August 12). Cenário Brasileiro de Parques Tecnológicos. Retrieved from www.anprotec.com.br

Baldwin, C. Y. \& Von Hippel, E. (2011) Modeling a paradigm shift: From producer innovation to user and open collaborative innovation. Organ. Sci., 22(6), 1399-1417
Barney, J. B. (1986). Strategic factor markets: expectations, luck and business strategy. Journal of Management Science, 32 (10), 1231-1241. doi: http://econpapers.repec.org/article/inmormnsc/v_3a32_3ay_3a 1986_3ai_3a10_3ap_3a1231-1241.htm

Barney, J. B. (1991). Firms resources and sustained competitive advantage. Journal of Management, Vol. 17, N. 1. Retrieved fromhttp:// jom.sagepub.com/content/17/1/99.abstract

Barney J. \& Hesterly, S. (2012). Strategic Management and Competitive Advantage. New Delhi, pp. 40-48.

Becker, W. \& Peters J. (1998). R\&D-competition between vertical corporate networks: Market structure and strategic R\&D-spillovers. Economics of Innovation and New Technology, 6, 51-72.

Bernstein, S. (2012). Does going public affect innovation? Doctoral dissertation. doi: http://nrs.harvard.edu/urn-3:HUL. InstRepos:10085978Cambridge, MA: Harvard University

Biedenbach, T. \& Muller, R. (2012). Absorptive, innovative and adaptative capabilities and their impact on Project and Project portfolio performance. Project Management, 30, 621-635.

Bobbio, N. (1987). The future of democracy: a defense of the rules of the game. Minneapolis: University of Minnesota Press.

Caner, T.; Sun, J. \& Prescott, J. E. (2014). When a firm's centrality in $\mathrm{R} \& \mathrm{D}$ alliance network is (not) the answer for invention: The interaction of centrality, inward and outward knowledge transfer, Journal of Engineering and Technology Management, 33, 193-209.

Carliss Baldwin, Eric von Hippel, (2011) Modeling a Paradigm Shift: From Producer Innovation to User and Open Collaborative Innovation. Organization Science, 22(6),1399-1417. doi: https://doi. org/10.1287/orsc. 1100.0618

Cassiman, B.; Veugelers, R. (2000). External technology sources: embodied or disembodied technology acquisition. doi: http://papers. ssrn.com/sol3/papers.cfm?abstract_id=224582

Chao, Chih-Yang; Lin, Yong-Shun; Cheng, Yu-Lin; Liao, Shu-Chia. (2011). The research on the relationship among market orientation, absorptive capability, organizational innovation climate and innovative behavior in Taiwan's manufacturing industry. African Journal of Business Management, 19 (5), 7855-7863.

CELTA. Centro Empresarial para Laboração de Tecnologias Avançadas. Retrieved from http://www.celta.org.br/

Cohen, W. \& Levinthal, D. (1990). Absorptive capacity: a new perspective on learning and innovation. Administrative Science Quarterly, 1 (35), 128-152.

CPI. Ciudad Politécnica da Innovación. (2015) Retrieved fromhttp:// cpi.upv.es 
Damanpour, F. (1991). Organizational innovation: A meta-analysis of effects of determinants and moderators. Academy of Management Journal, 34 (3), pp. 555 -590. doi: http://amj.aom.org/content/34/3/555.abstract

Dasgupta, P. \& David, P.A. (1994). Toward a new economics of science. Research Policy, 23 (5), 487-521.

Dosi, G., Nelson, R. \& Winter, S. G. (2000). Nature \& dynamics of organizational capabilities. New York: Oxford University Press, 1-22. Fabrizio, K. (2009). Absorptive capacity and the search for innovation. Research Policy, 38, 255-267.

Fallows J (2013). Dispatches from the Future. Joint Venture Silicon Valley: State of the Valley. San José, CA.

Filipova, V, Drozen, F. \& Kubankova, M. (2016). Product Innovation and Public Support - Case Study of SME in the Tourist Industry. Journal of Tourism and Services, 7 (12), 7-19.

Flatten, T. C; et al. (2011).A measure of absorptive capacity: Scale development and validation. Journal Elsevier-ESCP Europe, 98-116.

Fosfori, A. \& Tribo, J. A. (2008). Exploring the antecedents of potential absorptive capacity and its impact on innovation performance, Omega-International Journal of Management Science, 36 (2), 173-187.

Foss, N., J. (1997). Resources and strategy: a brief overview of themes and contributions. In: FOSS, N., J. (org.). Resources, firms and strategies: a reader in the resource-based perspective. $1^{\text {a }}$ ed. Oxford: Oxford University Press.

Graham, J., Amos, B. \& Plumptre, T. (2003). Governance Principles for Protected Areas in the 21st Century. Durban, UICN.

Groenewegen, J. (2004). Who should control the firm? Insights from New and Original Institutionalist Economics. Journal of Economic Issues, 38 (2), 353-61.

Hauknes, J. (1998). Services in innovation: innovation in services. Oslo: STEP group, STEP, Storgaten.

Humphrey, J. \& Schmitz, H. (2000). Governance and upgrading: linking industrial cluster and global value chain research. Brighton Institute of Development Studies. doi: https://www.ids.ac.uk/files/Wp120.pdf

IASP - International Association of Science Parks. (2015, June 15). Conceitos gerais. Retrieved from http://www.iasp.ws

IDEAS. (2015, October 15). Instituto IDEAS. Retrieved from http:// www.ideas.upv.es/

INOVAPARQ. Parque de Inovação Tecnológica de Joinville e Região. Retrieved from https://www.inovaparq.com.br/

Kapounek S, Krutilova V. (2016). Editorial Procedia - Social and Behavioral Sciences I, Volume 220; 2016. p. 251-260.
Kaufmann, D., Kraay, A. \& Mastruzzi, M. (2006). Governance Matters $V$ : aggregate and individual governance indicators for 1996-2005. The World Bank.

Kaufmann, D., Kraay, A. \& Mastruzzi, M. (2018, July 26). The Worldwide Governance Indicators. Retrieved fromhttps://datacatalog.worldbank.org/dataset/worldwide-governance-indicators

Knight, M. (2002). Governance in higher education corporations: A consideration of the constitution created by the 1992 act. Higher Education Quarterly, 56 (3), 276-286.

Kubota, L.C. (2009). As KIBS e a inovação tecnológica das firmas de serviços. Economia e Sociedade, Campinas, 18 (2), 349-369.

Lane, P. \& Lubatkin, M. (1998). Relative absorptive capacity and interorganizational learning. Strategic Management Journal, 19 (5), 461-477.

Lane, P., Koka, B. \& Pathak, S. (2006). The reification of absorptive capacity: a critical review and rejuvenation of the construct. Academy of Management Review, 31 (4), 833-863.

Lahorgue, M. A. (2006). Polos tecnológicos no Brasil: espontaneidade ou inovação social? I Congreso Iberoamericano de La Ciencia, Tecnología, Sociedad y Innovación.

Lichtenthaler, U. \& Lichtenthaler, E. (2010). Technology transfer across organizational boundaries: absorptive capacity and desorptive capacity. California Management Review, 53 (1), 154-170.

Lobianco, M. M. L. \& Ramos, A. S. M. (2004). Uso da internet no setor de hotelaria de recife: PE. RAE-Eletrônica, 3 (2).

Lopes, F. D. \& Baldi, M. (2009). Redes como perspectiva de análise e como estrutura de governança: uma análise das diferentes contribuições. RAP. Rio de Janeiro, 43 (5), 1007-1035.

Ma, X. F.; Kaldenbach, M. \& Katzy, B. (2014). Cross-border innovation intermediaries - matchmaking across institutional contexts. Technology Analysis \& Strategic Management, 26 (6), 703-716.

Markman, G., Phan, P., Balkin, D. \& Gianiodis, P. (2005). Entrepreneurship and university-based technology transfer. Journal of Business Venturing, 20 (2), 241-263.

Mattor, K., Betsill, M, Huayhuaca, C., Huber-Stearns, H., Jedd, T., Sternlieb, F., Bixler, P., Luizza, M. \& Cheng, A. S. (2014). Transdisciplinary research on environmental governance: A view from the inside. Environmental science \& policy, 4 (2), 90-100.

Maurer, C. C., Bansal, P. \& Crossan, M. M. (2010). Creating Economic Value Through Social Values: Introducing a Culturally Informed Resource-Based View. Organization Science. Articles in Advance, 1-17.

Melo, M. A. C \& Magacho, L. A. M. (2013). Services for People Innovation Park - Planning Methodologies, J. Technol. Manag. Innov, 8, Special Issue ALTEC, 208-218. 
Mills, K, Reynolds, E. \& Reamer, A. (2008, September 17). Clusters and Competitiveness: A New Federal Role for Stimulating Regional Economies. Washington, DC: Brookings Institution. doi: http://www. brookings.edu/research/reports/2008/04/competitiveness-mills

Mueller, M., Schmidt, A. \& Kuerbis, B. (2013). Internet Security and Networked Governance in International Relations. International Studies Review, Vol. 15, pp. 86-104. doi: http://onlinelibrary.wiley.com/ doi/10.1111/misr.12024/pdf

OECD. (2015, August 18). Manual de Oslo. Retrieved fromhttp:// www.oecd.org/sti/inno/2367580.pdf

Peteraf, M.A. (1993). The cornerstones of competitive advantage: a resource-based view, Strategic Management Journal, 14, 179-191.

Pipan, K. K., Gomiscek, B. \& Mayer, J. (2012). Exploratory study of quality and excellence approaches and continuous improvement from the perspective of new institutionalism. Journal for East European Management Studies, 3, 313-332.

Pirayesh, A., Doumeingts, G., Seregni, M., Gusmeroli, S., Westphal, I., Gonzalez, L., Hans, C., Arino, M. J. N, Eugenio, A. C. \& Laskurain, A. (2018). Conceptual Framework for Product Service Systems, 6 (2).

Qsrinternational. Software Nvivo. (2015, August 10). Retrieved fromhttp://www.qsrinternational.com

Robeson, D. \& O'connor, G. (2007). The governance of innovation centers in large established companies. J. Eng. Technol. Manage, 24, 121-147.

Saito, R. \& Silveira, A. D. M. (2008). Governança corporativa: custos de agência e estrutura de propriedade. Revista de Administração de Empresas, 48 (2), 79-86.

Scott, W. R. (1987). The adolescence of institutional theory. Administrative Science Quarterly, 32 (4), 493-511.

Scott, W. R. (2004). Institutional theory: contributing to a theoretical research program. In: Smith K. G.; Hittm. A. (Eds)Great Minds in Management.

Schmitz, H. \& Humphrey, J. (2000). Governance and Upgrading: Linking Industrial Cluster and Global Value Chain Research. In: IDS Working Paper 120. IDS - Institute of Development Studies. UK.

Schmidt, S. \& Balestrin, A. (2015). Brazilian Incubators and Science Parks' Resources and R\&D Collaboration. J. Technol. Manag. Innov, 10 (3), 32-43.

Schreyöegg, G. \& Kliesch-Eberl, M. (2007). How dynamic can organizational capabilities be? Towards a dual-process model of capability dynamization. Strategic Management Journal, 28 (9), 913-933.

Schumpeter, J. A. Teoria do desenvolvimento econômico: uma investigação sobre lucros, capital, crédito, juro e ciclo econômico; tradução de Maria Sílvia Possas. São Paulo: Nova Cultural, 1997.
Spolidoro, R. (1999). Habitats de inovação e empreendedores: agentes de transformação das estruturas sociais. Techbahia: Baiana Tenol.

Sureeyatanapas, P., Poophiukhok, P. \& Pathumnakul, S. (2018). Green initiatives for logistics service providers: An investigation of antecedent factors and the contributions to corporate goals. Journal OfCleaner Production, 191, 1-14.

Tabas, J. \& Beranova, M. (2016). Innovation Life Cycle. 19th International Conference Enterprise and Competitive Environment, 513-521.

Teece, D.J., Pisano, G. \& Shuen, A. (1997). Dynamic Capabilities and Strategic Management. Strategic Management Journal, 18 (7), 509-533.

Van den Bosch, F.A.J., Volberda, H.W. \& de Boer, M. (1999). Coevolution of firm absorptive capacity and knowledge environment: organi- 56 Clusters and knowledge zational forms and combinative capabilities. Organizational Science, 10(5), 551-68.

Vázquez, B. G. (2007). Red interorganizativa de cooperación en areas tecnológicas, J. Technol. Manag. Innov. 2007, 2 (2), 125-135.

Vega-Jurado, J., Kask, S. \& Manjarrés-Henriquez, L. (2017). University industry links and product innovation: cooperate or contract? J. Technol. Manag. Innov, 12 (3), 1-8.

Veugelers, R. (1997). Internal R\&D expenditures and external technology sourcing. Research Policy, 6, 303-315.

Veugelers, R \& Cassiman, B. (1999). Make and buy in innovation strategies: evidence from Belgian manufacturing firms. Research Policy, 28, 63-80.

Virtanen, M., Heimonen, I. \& Sepponen, M. (2014). Stakeholder analysis and questionnaire showing the way for the development of business and service models, Renewable Energy Research Conference, 58, 51-57.

Xie, X. M.; Wang, L. J. \& Zeng, S. X. (2018). Inter-organizational knowledge acquisition and firms' radical innovation: A moderated mediation analysis, Journal of Business Research, 90, 295-306.

Wang, M. C.; Chen, P. C. \& Fang, S. C. (2018). A critical view of knowledge networks and innovation performance: The mediation role of firms' knowledge integration capability, Journal of Business Research, 88, 222-233.

Werle, F. O. C. (2011). Políticas de avaliação em larga escala na educação básica: Do controle de resultados à intervenção nos processos de operacionalização do ensino. doi: http://www.scielo.br/pdf/ensaio/ v19n73/03.pd

Winter, S. G. (2003). Understanding Dynamic Capabilities. Strategic Management Journal, 24, 991-995. 
Yang, C-H., Motohashi, K. \& Chen, J. R. (2009). Are new technologybased firms located on science parks really more innovative? Evidence from Taiwan. Research Policy, 38 (1), 77-85.

Zahra, S. A. \& George, G. (2002). Absorptive Capacity: A review, Reconceptualization and extension. Academyof Management Review, 27, 185-203.
Zahra, S., Sapienza, H. \& Davidsson, P. (2006). Entrepreneurship and Dynamic Capabilities: A Review, Model and Research Agenda. Journal of Management Studies, 43 (4), 917-955. doi:10.1111/j.14676486.2006.00616.x

Zouain, D. M. (2003). Contribuições para o planejamento de parques tecnológicos urbanos. Revista Gestão \& Tecnologia, 2 (1), 1-13. 


\section{Appendix 1}

Figure 4. Framework for the development of capacities in innovation habitats

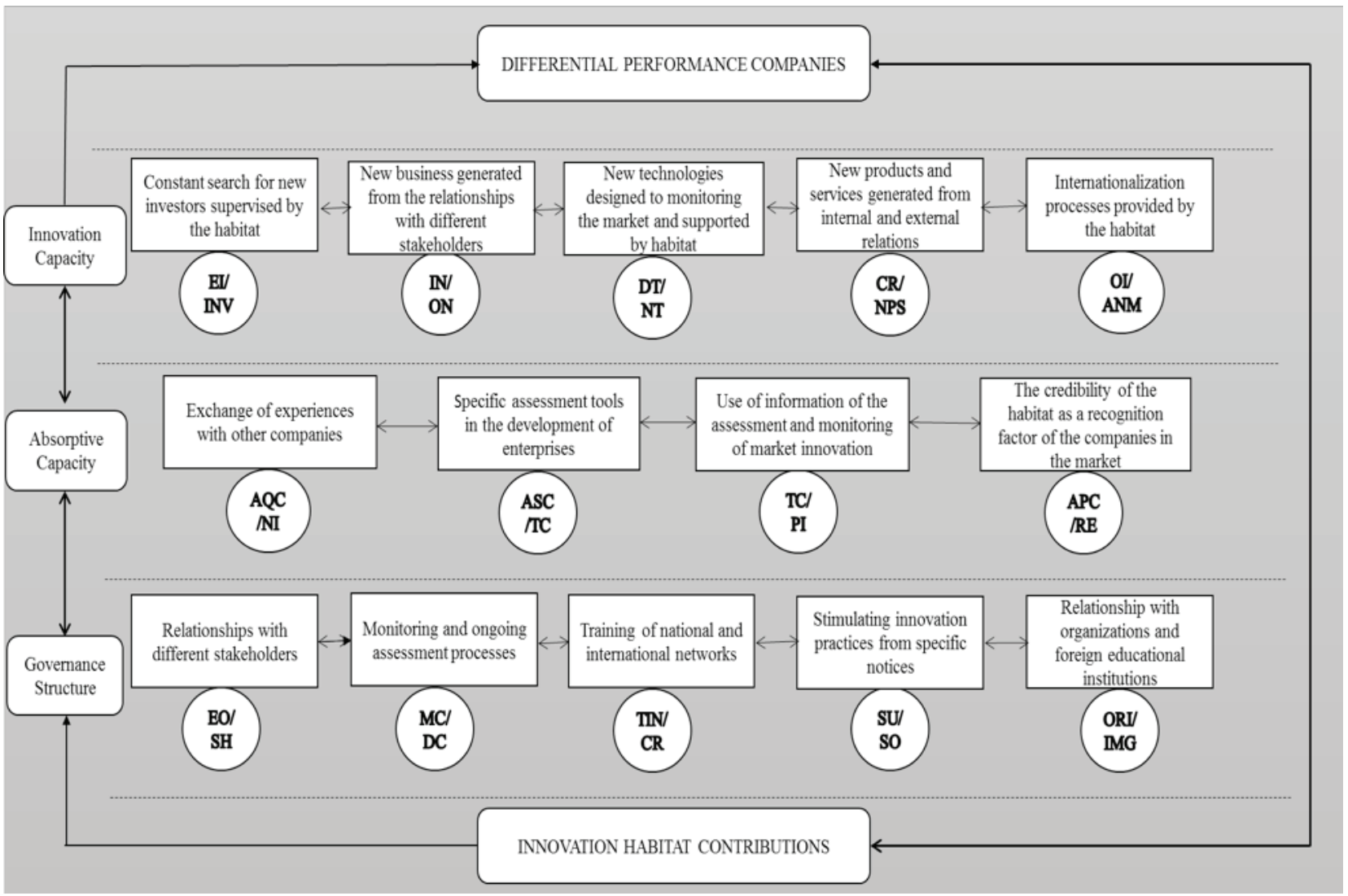

Legend: Governance Structure: Category: EO - Organizational Structure / Indicator: SH - Stakeholders. Category: MC - Growth Facility / Indicator: DC - Capacity building. Category: TIN - Technology, innovation and networking / Indicator: CR - Network Cooperation. Category: SU - Sustainability / Indicator: S - Social. Category: ORI - international relations Opportunities / Indicator: IMG - integration with global markets. Absorptive capacity: Category: AQC - Acquisition of knowledge / Indicator: NI - Internal Networking. Category: ASC Assimilation of knowledge / Indicator: TC - Training and capacity building. Category: TC - Knowledge transfer / Indicator: PI - Innovation processes. Category: APC - Application of knowledge / Indicator: RE - Recognition. Innovation Capacity: Category: EI - Boosting Innovation / Indicator: INV - Investor. Category: IN - Innovativeness / Indicator: ON - Business opportunities. Category: DT - Technological development / Indicator: NT - New technologies. Category: CR - Creation / Indicator: NPS - New products and services. Category: HI - International Opportunities / Indicator: ANM - Access to new markets. 
